\title{
Labor (Im)mobility and the Politics of Trade Protection in Majoritarian Democracies
}

\author{
Bumba Mukherjee Penn State University \\ Dale L. Smith Florida State University \\ Quan Li Texas A\&M University
}

\begin{abstract}
The two workhorse models of trade, Heckscher-Ohlin and Ricardo-Viner, provide leverage in explaining how societal groups divide over trade protection. Tension between the two trade models has significantly influenced the scholarship of trade politics, with explanations of trade politics adopting either the factor-based approach or the industry-based framework. No study has investigated how changes in factor mobility as a continuous variable influence the change in trade protection as a policy outcome. Building on recent scholarship on factor mobility, this article models explicitly how intersectoral labor (im)mobility and political competition between parties affect changes in trade protection in majoritarian democracies. The theoretical model predicts that when intersectoral labor mobility decreases governments in majoritarian democracies are more likely to raise trade barriers. We test this prediction in a time-series, cross-sectional sample of 32 OECD and non-OECD majoritarian democracies observed between 1980 and 2000. The empirical results corroborate our theory and remain robust when we control for alternative explanations, employ different estimation techniques, and use different measures of trade protection.
\end{abstract}

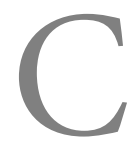

onflict over trade policy is a constant feature in the national political arena of any democracy. Societal groups and economic sectors who benefit from international trade are locked in a perennial struggle with others who lose to import competition, as each side attempts to press the government to enact its preferred policies. Two longestablished economic models of trade enable us to anticipate how societal groups will divide over this issue. The standard Heckscher-Ohlin (H-O) model assumes that factors are mobile between sectors and concludes that trade preferences form along factor lines. In contrast, the Ricardo-Viner (R-V) model assumes that factors are immobile between sectors and predicts trade preferences according to industrybased divisions. Tension between the two trade models has significantly influenced the scholarship of trade politics. Explanations of trade politics have adopted either the factor-based approach ${ }^{1}$ or the industry-based framework. ${ }^{2}$ Empirical tests of these two approaches have produced mixed evidence. ${ }^{3}$ The rare effort to integrate the two approaches has largely been thwarted by their diametrically opposed assumptions regarding factor mobility between industries in a country. ${ }^{4}$ Only recently have scholars begun to relax the simple dichotomous assumption on factor mobility, conceptualizing it as a continuum that varies between countries and over time, and thus

\footnotetext{
${ }^{1}$ Studies that use the factor-based approach include Rogowski (1987), Milner and Judkins (2004), Dutt and Mitra (2005), and Milner and Kubota (2005). Baker (2005) extends the Heckscher-Ohlin model to explain trade policy preferences at the individual level, while Frieden (1991) uses the same model to examine the politics of financial liberalization.

${ }^{2}$ See, for example, Lavergne (1983), McGillivray (2005), and Grossman and Helpman (2005).

${ }^{3}$ Magee (1978) and Irwin $(1994,1996)$ find that lobbying activity and political cleavages with respect to trade policy in the United States follow industry rather than factor lines. Scheve and Slaughter (2001) and Mayda and Rodrik (2005) find that the Heckscher-Ohlin model accounts for trade policy preferences using American and cross-national survey data, respectively.

${ }^{4}$ Mayer (1984) integrates the median voter model of majoritarian electoral politics with the Heckscher-Ohlin model and the specific factors model. Although his model produces novel insights, it conceptualizes factor mobility in dichotomous terms. This is not only empirically unrealistic but also weakens the explanatory and predictive power of his model.
}

The Journal of Politics, Vol. 71, No. 1, January 2009, Pp. 291-308

doi:10.1017/S0022381608090191 
opening the door for integrating the factor-based and industry-based approaches to trade politics. ${ }^{5}$ So far, however, no study has investigated how changes in factor mobility as a continuous variable influence the change in trade protection as a policy outcome. ${ }^{6}$ This article takes a first step in filling this important gap.

In this article, we initiate a rigorous analysis of the impact of labor mobility (or lack thereof) on trade policy. We choose to focus on the following question: How does the degree of labor (im)mobility (i.e., specificity) affect changes in trade protection in majoritarian democracies? To address this question, we build on Mayer's (1984) model of trade policy to derive the conditions under which political parties have incentives to increase or decrease trade protection, but unlike Mayer's (1984) model that formalizes factor mobility in dichotomous terms, the degree of intersectoral labor mobility is formalized here as a continuous parameter. In our model, specific-type (mobile-type) voters face high (low) adjustment costs when changing jobs between sectors and hence, rationally prefer high (low) tariffs. As the median voter's labor specificity increases, the median voter prefers trade protection. To maximize votes, political parties in a majoritarian democracy will pander to the median voter and raise tariffs in equilibrium. We find strong empirical evidence for our argument in an analysis of 32 OECD and non-OECD majoritarian democracies observed between 1980 and 2000. The empirical results remain robust when we restrict the sample to either OECD or non-OECD countries, vary the model specification, employ different estimation techniques, and use several alternative measures of trade policy.

As a limitation, our research focuses on majoritarian democracies only. To generate theoretical insights into the impact of labor specificity as a continuous parameter on trade policy, we must rely on a formal model of politics. The median voter framework, which we employ here, provides a reasonable characterization of party competition and policymaking in majoritarian democracies, but not necessarily in others. Despite this limitation, our study makes several novel contributions to the literature on trade politics.

Theoretically, our model is among the first to formally incorporate and assess how the variation in

\footnotetext{
${ }^{5}$ Hiscox (2002) is the first to provide careful and systematic evidence for how variation in intersectoral labor mobility affects the formation of different types of political coalitions in six advanced industrial democracies.

${ }^{6}$ Wacziarg and Wallack (2004) recognize that variation in intersectoral labor mobility may affect trade policy, but do not explicitly theorize or statistically assess the relationship.
}

intersectoral labor mobility affects the change in trade protection in majoritarian democracies. The model treats labor specificity as a continuum rather than a dichotomy, an advance over previous models of trade policy (e.g., Mayer 1984). In addition, unlike Hiscox' (2002) study that focuses only on how varying factor mobility affects the formation of different political coalitions in just six countries, we substantially extend his work to theorize and empirically test how variation in intersectoral labor specificity affects trade policy outcomes. Finally, while existing studies focus on how the strength of political parties and the geographic concentration of industries explain differences in trade protection in majoritarian democracies (Grossman and Helpman 2005; McGillivray 2004), our study argues and shows empirically that the extent of labor specificity plays an important role in accounting for trade policy formation in these countries.

Our analysis also offers two important empirical innovations. First, previous empirical work on trade policy has primarily focused on advanced industrial democracies (e.g., Ehrlich 2007; Hiscox 2002; Kono 2006; McGillivray 2004; Mansfield and Busch 1995; Milner and Judkins 2004) and occasionally on developing countries only (e.g., Henisz and Mansfield 2006; Milner and Kubota 2005). We test our argument in both developed and developing countries. Although the theoretical model dictates the empirical focus on majoritarian democracies, our argument holds empirically across different development levels. Second, much of previous empirical research on trade policy relies on cross-sectional data and studies the level of trade protection (e.g., Dutt and Mitra 2005; McGillivray 2004). These analyses find it difficult to establish causation since cross-sectional association could be an artifact of unobserved heterogeneity. Our empirical analysis studies the change in trade protection in a pooled time-series design, which lends more confidence to the support of the statistical finding for the underlying causal mechanism.

The rest of the paper proceeds as follows. First, we present the formal model under majority voting and the implications from this model. In the following three sections, we describe our empirical research design, statistical findings, and robustness tests. In the last section, we conclude the article with a discussion of the implications of this study.

\section{The Model}

We build on Mayer's (1984) seminal work and offer a Downsian model to study how intersectoral 
labor-specificity in tradable sectors influences trade protection in a majoritarian democracy. While our model shares some important similarities with Mayer's (1984) model, there are crucial differences as well. First, unlike Mayer's model which assumes that labor is perfectly mobile across sectors, we assume that the labor market has imperfections and nominal rigidities that impede mobility. Second, Mayer (1984) assumes constant returns to scale in production in his model, while we assume weakly increasing returns to production. ${ }^{7}$ Third, Mayer's model studies how relative endowments influence tariffs, while we focus on how variations in labor specificity among voters in tradable sectors affect trade protection. These differences between our model and Mayer's (1984) have important implications that are explored below. We focus on intersectoral labor specificity across all the main tradable sectors since (1) our objective is to explain how the extent of labor specificity within the aggregate labor force affects voters' preferences over trade protection in a majoritarian democracy and (2) because our model focuses on goods produced in tradable sectors. ${ }^{8}$

To maintain analytical tractability, we adopt some simple modeling assumptions. First, we assume that the formation of single party majority governments is common in majoritarian democracies. This assumption is plausible because studies have established that single party majority governments are extremely common in majoritarian democracies, while the formation of coalition governments is the norm in PR systems (Iverson and Soskice 2006). Second, we assume from Duverger's law that majoritarian systems are dominated by two main parties. We submit that this is a restrictive assumption. To ensure that our empirical results are not influenced by this assumption, our statistical analyses control for differences in the number of political parties, party strength, veto players, and government partisanship.

\footnotetext{
${ }^{7}$ We follow Grossman and Helpman (2005) who also assume weakly increasing returns in production. However, unlike our model, Grossman and Helpman (2005) focus on the impact of party discipline and not intersectoral labor specificity on trade protection.

${ }^{8}$ As shown by economists such as Blanchard and Katz (1997) and Rama (2003) workers in tradable sectors form an important component and the bulk of the aggregate labor force in nonOECD and most OECD economies since the postwar period. Thus focusing on workers in tradable sectors-who have preferences over trade policy-will help us understand how voters' preferences in the aggregate labor force influences trade protection.
}

Third, following well-known political economy models of trade in majoritarian democracies by Mayer (1984) and Grossman and Helpman (2005), the political parties in our model have information about the median voter's preference over trade policy and thus have incentives to locate their tariff policy platforms at the median voter's position to maximize votes and their probability of survival in office; that is, parties have incentives to converge to the median voter's position. Although scholars such as Cox (1990) and Myerson (1993) have shown that the convergence result may not hold, we adopt the aforementioned assumption for two reasons.

First, a key theoretical objective of our paper is to build mathematically on Mayer's (1984) medianvoter model of trade to understand how the degree of labor specificity, which is formalized via a continuous distribution in our model, influences trade protection in majoritarian democracies. Hence, we maintain consistency with the Downsian approach used by both Mayer (1984) and Grossman and Helpman (2005) to model trade policy in majoritarian countries. Second, empirical analyses of elections in developed democracies by Huber and Powell (1994), Powell (2000), and Powell and Vanberg (2000) suggest that on average party positions in majoritarian systems are closer to the median voter than in PR democracies. ${ }^{9}$ In a more extensive (and recent) empirical study of 55 elections across the developed and developing world from 1994 to 2003, Blais and Bodet find that in majoritarian systems, "there is stronger pressure for each party to adopt positions as close as possible to those of the median voter" $(2006,1260)$. Therefore, the Downsian approach we adopt, where parties have incentives to converge to the median voter's position, is empirically plausible. ${ }^{10}$

The actors in the model are (1) two political parties (A and $B$ ) that want to maximize their probability of obtaining office, (2) labor-specific (i.e., specific-type) voters in tradable sectors for whom the costs of moving between different sectors is high, and (3) mobile-type voters who change jobs in different sectors with relative ease. We derive the tariff

\footnotetext{
${ }^{9}$ In particular, see Table 1 in Huber and Powell (1994) which summarizes the results they obtain for party (policy) positions in majoritarian and PR countries.

${ }^{10}$ That said, we statistically control for those factors in majoritarian democracies, including the number of political parties, veto players, government partisanship, and variation in party strength, that have been previously identified (e.g., Cox 1990) as weakening the convergence result in the Downsian setting. This ensures that our empirical results are not driven by the assumption of convergence.
} 
preference of specific-type voters before reporting the equilibrium solution and comparative static results.

Consider a two-factor, small-open economy of a majoritarian democracy that produces two goods: good $g$ which is the importable and good $y$ which is the exportable. $g$ is produced with labor and sectorspecific capital. Following partial-adjustment theory in labor economics (see Hamermesh 1990; Nickell 1985), we assume that the labor market in the economy is imperfect and characterized by nominal rigidities resulting from structural factors such as social security systems and minimum wage legislation that impede intersectoral labor mobility. ${ }^{11} \mathrm{Em}$ pirical work by Blanchard and Wolfers (2000) and Korenman and Neumark (2000) support the notion that all countries are characterized by nominal rigidities that prevent smooth movement of labor across sectors even when the economy faces exogenous shocks. Since there exists nominal rigidities in the labor-market, the total return to capital from producing $g$ is not a strictly but rather a weakly convex function $\Pi\left(p_{g}\right)$ where $p_{g}$ is the domestic price of $g$. Let $y$ be the numeraire good, which is produced with one unit of labor per unit of output. We normalize the domestic and world prices of the numeraire good to one. $g$ and $y$ are produced under weakly increasing returns to scale. The economy is populated by voters where each voter is denoted by $i$. There are two types of voters. The first type is the labor-specific ("specific-type") voter denoted as $\alpha=1$, and the second type is the relatively mobile (mobile-type) voter labeled as $\alpha=0$. We later relax this dichotomy and assume that labor specificity among voters is continuous and normally distributed.

In the model, each voter consumes good $g$ and $y$. More specifically, voters receive indirect utility from three sources. First, the indirect utility for voter $i$ from consumption is $l+S\left(p_{g}\right)$ where $S\left(p_{g}\right)$ is the surplus obtained from consuming $g$ and $l$ is the voter's income from labor net of lump-sum taxes and transfers. ${ }^{12}$ Second, each voter receives a share from national tariff revenues. If all world market prices are normalized to one, the domestic price of $g$ is one plus the tariff rate, i.e., $p_{g}=1+\tau$, where $\tau$ is the tariff rate. The tariff revenue from imports $M$ which is distributed as a lump sum to voters is $\tau M(\tau)$ and

\footnotetext{
${ }^{11}$ Unlike Adsera and Boix (2002), we do not analyze the link between government spending and trade barriers since it is beyond the scope of our study. But we control for government spending in our empirical model when assessing labor specificity's impact on trade protection.

${ }^{12}$ Note that $\partial S\left(p_{g}\right) / \partial p_{g}=-g^{d}\left(p_{g}\right)<0$ where $-g^{d}\left(p_{g}\right)$ is the total demand for $g$.
}

$M^{\prime}(\tau)<0$. Third, specific-type voters place substantial weight $(w)$ on the gains from capital invested in producing $g$ because their livelihood is dependent on $g$. The indirect utility from capital invested in $g$ is $\alpha\left(w \Pi\left(p_{g}\right)\right)$. From the above information, the indirect utility for specific-type voters can thus be defined as

$$
v_{i}^{\text {specific }}(\tau)=l+\alpha[w \Pi(\tau)]+[S(\tau)+\tau M(\tau)]
$$

Lemma 1: The optimal tariff rate preferred by specifictype voters (workers) is $\tau^{\text {Specific }}=2 \frac{g(\tau)}{-M^{\prime}(\tau)}>0$.

The proof of this lemma, and other results from the formal model, is in the online appendix at http:// journalofpolitics.org/.

Lemma 1 suggests that specific-type voters rationally prefer higher and strictly increasing tariffs. The intuition that explains this result is three-fold. First, if good $g$ cannot compete against import competition, then specific-type voters, whose incomes are tied to the economic fortunes of $g$, face the risk of prolonged unemployment spells owing to high adjustment costs of changing jobs between different sectors. Second, as labor market imperfections and nominal rigidities impede intersectoral labor mobility, specific-type voters find themselves stuck in the sector threatened by import competition. Third, an increasing tariff raises the returns to capital invested in $g$. This, in turn, directly increases the utility of specific-type voters. These three reasons motivate specific-type voters to demand higher tariffs against imports. ${ }^{13}$

Given the result in Lemma 1, we examine below how competition between political parties in a majoritarian democracy affects trade protection. The extent of each voter's labor specificity in tradable sectors is now defined by the parameter $\alpha_{i}^{\text {specific }}$ which is continuous and normally distributed with cumulative distribution function $F$. Hence the extent of specificity among voters in the labor force ranges from highly mobile to highly specific. Under a normal distribution, the degree of the median voter's specificity is defined as $\alpha^{M}$ while the mean voter's degree of specificity is $\alpha^{\mu} .{ }^{14}$ As mentioned earlier, there are two parties in the model, $P \in\{A, B\}$ denotes the tariff rate proposed by parties and implemented by the winning party in office. The objective of the two parties is to choose their respective tariff

\footnotetext{
${ }^{13}$ If $p_{g}$ increases, the utility of specific-type voters increases for $d\left(2 \pi\left(p_{g}\right) / d p_{g}=2 g\left(p_{g}\right)>0\right.$.

${ }^{14}$ The median and mean voter's degree of specificity is equal, $\alpha^{M}=\alpha^{\mu}$, when $\alpha_{i}^{\text {specific }} \sim N\left(0, \sigma_{\alpha}^{2}\right)$.
} 
rate $\tau^{A}, \tau^{B}$ to maximize their probability $(\pi \in(0,1))$ of winning and then surviving in office,

$$
\left.\begin{array}{l}
\pi\left(\tau^{A}, \tau^{B}\right) \text { for Party A } \\
1-\pi\left(\tau^{A}, \tau^{B}\right) \text { for Party B }
\end{array}\right\}
$$

Both parties have incentives to set their tariff policy in equilibrium at the median voter's position to maximize votes. We formally solve and characterize the aforementioned equilibrium tariff level from $A$ 's objective function because in Nash equilibrium Party B's optimal tariff choice will be similar. We then examine how the equilibrium tariff level changes when the degree of labor-specificity in the economy's labor force increases. Since labor specificity in the economy is normally distributed, Party $A$ maximizes its probability of surviving in office, it chooses an optimal tariff rate such that

$$
\begin{aligned}
\frac{\partial \pi\left(\tau^{A}, \tau^{B}\right)}{\partial \tau^{A}}= & \alpha_{i}^{\text {specific }}\left(g(\tau)-\tau M^{\prime}(\tau)\right) \\
& -\alpha_{i}^{\text {mobile }}\left(\tau M^{\prime}(\tau)-g(\tau)\right)
\end{aligned}
$$

The derivation of the functional form of (3) is described in the proof for lemma 1. From (3), we obtain,

Lemma 2: In a symmetric and unique Nash equilibrium, the optimal tariff rate-which is also the median voter's preferred tariff policy-implemented by the political parties in a majoritarian democracy is: $\tau^{A^{*}}=\tau^{B^{*}}=\tau^{M^{*}} \equiv \frac{g(\tau)\left(\alpha_{i}^{\text {specific }}+\alpha_{i}^{\text {mobile }}\right)}{M^{\prime}(\tau)\left(\alpha_{i}^{\text {mobile }}-\alpha_{i}^{\text {specijic }}\right)}$.

Because the Nash equilibrium tariff level in Lemma 2 is the median voter's preferred tariff rate, $\mathrm{A}$ and $\mathrm{B}$ have incentives to not deviate from the equilibrium policy position; they will gather fewer votes if they do. Comparative statics conducted on the Nash equilibrium tariff level in Lemma 2 with respect to $\alpha_{i}^{\text {specific }}$ leads to the main substantive result,

Proposition 1: The Nash equilibrium tariff level strictly increases when intersectoral labor specificity increases in a majoritarian democracy. More formally, $\frac{d \tau^{M^{*}}}{d \alpha_{i}^{\text {specific }}}>0$.

The mathematical basis for the result in Proposition 1 is simple. It suggests that when the degree of intersectoral labor specificity increases, the distribution of labor specificity in the economy will become negatively skewed. As a result, the median voter will be more immobile than the mean voter and in effect the median voter will be a specific-type individual characterized by a high degree of specificity. This is illustrated in Figure 1, which shows that when labor specificity increases in tradable sectors within majoritarian democracies, the median voter's specificity is

\section{FIgURE 1 Equilibrium Tariff Rate for Increase in Labor Specificity}

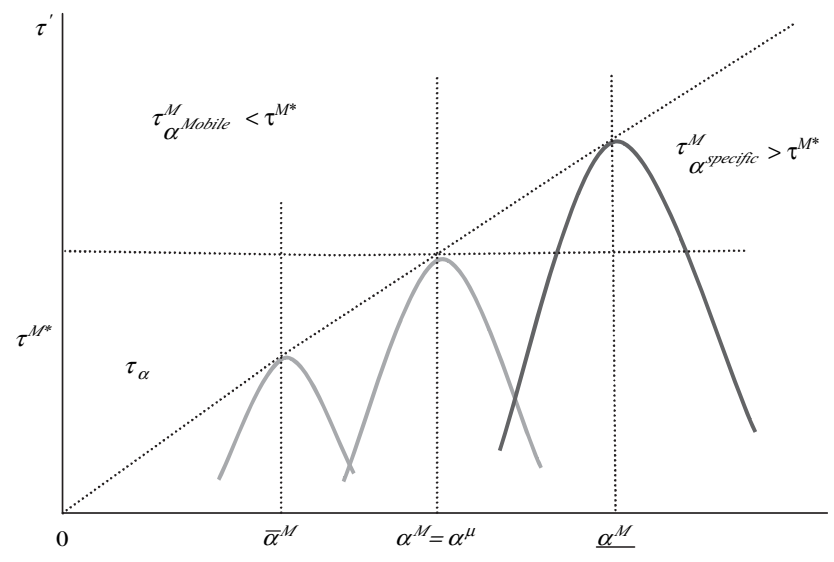

higher than that of the mean voter. Consequently, the realized equilibrium tariff level increases, as claimed in Proposition 1. Conversely, if labor specificity is low such that the median voter's specificity is lower than that of the mean voter, the equilibrium tariff level is lower than the derived Nash equilibrium tariff level. Hence, less technically, from Proposition 1, we expect that under the majoritarian system, a rise in intersectoral labor specificity (i.e., a decline in labor mobility) will lead to an increase in trade protection, while a decline in labor specificity will have the opposite effect.

A less technical explanation of the causal intuition behind Proposition 1 is as follows. As suggested earlier, labor market imperfections and nominal rigidities impede intersectoral labor mobility. Further, the government cannot substantially alter, especially in the short run, these rigidities in order to increase the speed of intersectoral labor movements. Consequently, two effects will occur. First, given nominal rigidities and thus a weakly convex profit function, capital is likely to remain immobile. This will lead over time to an increased concentration of the labor force across tradable sectors in sectorspecific production. Second, since the costs of changing jobs between different sectors are high for specific-type voters, they have incentives to remain immobile. When the incentives for labor to move between sectors are reduced and labor remains concentrated in sector-specific production, the speed of intersectoral labor adjustment is reduced and the proportion of specific-type voters increases over time, i.e., $\alpha_{i}^{\text {specific }}>0 .{ }^{15}$

\footnotetext{
${ }^{15}$ Specifically, the net flow of new workers in the pool of specifictype voters will increase if nominal rigidities persist, thus leading to an increase in the share of specific-type voters.
} 
As discussed above, an increase in the share of specific-type voters results in the median voter being a specific-type individual who from Lemma 1 rationally prefers higher tariffs. Since the median voter strictly prefers higher tariffs in this case, the two political parties will have incentives to increase the Nash equilibrium tariff and not to deviate from implementing higher tariffs, in order to maximize their votes. Additionally, when labor specificity rises in a majoritarian democracy, parties will implement higher tariffs in order to protect specific-type voters from unemployment owing to import competition, raise the returns to capital invested in $g$, and by implication, increase the monetary benefits received by specific-type voters in the tradable sector. Less technically, Proposition 1 implies,

H1: If the degree of intersectoral labor specificity of voters in the labor force increases in a majoritarian democracy, then trade protection will increase.

\section{Empirical Research Design}

We test Hypothesis 1 systematically in several steps. First, since Hypothesis 1 applies to majoritarian democracies, we start by testing this hypothesis on a full sample (including OECD and non-OECD states) of 32 majoritarian democracies ${ }^{16}$ between 1980 and 2000 that are listed in Table $1 .{ }^{17}$ Second, since non-OECD and OECD countries differ significantly along various dimensions (the level of development, the extent of labor specificity, etc.), we divide our global sample into OECD and non-OECD subsamples and test Hypothesis 1 within each group. ${ }^{18}$ Third, we check the robustness of our results, particularly with respect to a variety of trade-policy measures described below.

Based on the formal model's result, our dependent variable should measure the change in trade

\footnotetext{
${ }^{16}$ The democracies in our sample satisfy Przeworski et al.'s (2000) definition of democracy.

${ }^{17}$ Following Lijphart (1999), the majoritarian sample includes states with plurality rule, absolute and qualified majority requirements, the limited vote, alternative vote or the single nontransferable vote. Countries with a mixed electoral system that use the majoritarian and PR system to elect representatives are excluded since our theory applies only to majoritarian democracies.

${ }^{18} \mathrm{~A}$ total of 10 majoritarian democracies are observed in the OECD world between 1980 and 2000, while 22 majoritarian countries are observed in the non-OECD world in this time period.
}

\section{TABLE 1 List of All Majoritarian Democracies in Sample}

\begin{tabular}{|c|c|c|}
\hline Country & Years & OECD \\
\hline Australia & 1980-2000 & Yes \\
\hline Bahamas & $1980-2000$ & No \\
\hline Bangladesh & 1991-2000 & No \\
\hline Barbados & $1980-2000$ & No \\
\hline Belize & $1980-2000$ & No \\
\hline Canada & 1980-2000 & Yes \\
\hline France & 1988-2000 & Yes \\
\hline Ghana & 1980 & No \\
\hline Grenada & 1984-2000 & No \\
\hline Haiti & 1995-2000 & No \\
\hline India & 1980-2000 & No \\
\hline Italy & 1993-2000 & Yes \\
\hline Jamaica & 1980-2000 & No \\
\hline Japan & 1980-1995 & Yes \\
\hline Kyrgyztan & 1995-1999 & No \\
\hline Macedonia & 1994-1997 & No \\
\hline Malawi & 1994-2000 & No \\
\hline Mexico & 1999-2000 & Yes \\
\hline Mongolia & 1992-1997 & No \\
\hline Nepal & 1991-2000 & No \\
\hline New Zealand & 1980-1995 & Yes \\
\hline Nigerial & 1980-1982 & No \\
\hline Nigeria2 & 1999-2000 & No \\
\hline Pakistan1 & 1989-1999 & No \\
\hline Philippines & 1986-2000 & No \\
\hline South Korea & 1988-2000 & Yes \\
\hline Thailand1 & 1983-1990 & No \\
\hline Thailand2 & $1992-2000$ & No \\
\hline Trinidad \& Tobago & 1980-2000 & No \\
\hline Uganda & $1980-1984$ & No \\
\hline Ukraine & 1994-1997 & No \\
\hline United Kingdom & 1980-2000 & Yes \\
\hline United States & 1980-2000 & Yes \\
\hline Zambia & 1991-2000 & No \\
\hline
\end{tabular}

Notes: Data for coding observed democracies for 1980-2000 with a majoritarian electoral system is drawn from Golder (2004) and the World Bank's Database of Political Institutions, Beck et al. (2001).

protection. The main indicator that we use is the annual change in the import duty coverage ratio ( $\Delta$ import duties), which is defined as the total value of a country's import duties divided by the total value of its imports in a given year $(t)$. Data for this variable is from the World Bank's World Development Indicators [WDI] (2003) and the Global Trade Analysis Project [GTAP] (2006), version 6.

For robustness tests, we use three alternative measures of trade protection. The first measure is change in collected tariff revenue ( $\Delta$ tariff revenue) from the World Bank's WDI (2003). It is defined as 
change in the ratio of total tariff revenue to the total value of imports from year $t-1$ to year $t$. The second measure is from Hiscox and Kastner (2002). They generate measures of protection using the importingcountry specific and time-specific effects from an augmented gravity model where relative factor endowment differentials are used as additional variables to capture factor-proportions type effects. This measure captures the implicit protection through substitutes (including domestic policies adopted) of standard trade policy measures. We use the change in the Hiscox-Kastner measure as our dependent variable.

The third measure is an endowment-corrected measure of trade openness that is operationalized from Leamer (1988). Following Leamer, our measure of trade openness is based on the idea that the coefficient of trade openness $(X+M / G D P)$ is positively correlated with the difference in the endowments between a country and the rest of the world. Therefore, we estimate the regression

$$
\begin{aligned}
(X+M / G D P)_{i t}= & c+b_{1} \ln \left(\text { area }_{i}\right)+b_{2} \ln \left(g d p p c_{i t}\right) \\
& +b_{3} \ln \left(\text { dist }_{i}\right)+\gamma_{1} \Delta_{i k t}^{2}+\gamma_{2} \Delta_{i l t}^{2} \\
& +\theta\left(\text { trend }_{t}\right)+u_{i t}
\end{aligned}
$$

where $\ln \left(\right.$ area $\left._{i}\right)$ is the log of the size of country $i$ in square miles, $\ln \left(g d p p c_{i t}\right)$ is log GDP per capita of country $i, \ln \left(\right.$ dist $\left._{i t}\right)$ is the average of the distance between country $i$ and its 20 most important partners and $\Delta_{i k t}^{2}$ (and $\Delta_{i l t}^{2}$ ) is the difference between country $i$ 's and world's effective endowment of capital $(k)$ and labor (l) (drawn from Lee 1992 and GTAP 2006). ${ }^{19} \mathrm{~A}$ time trend is included to account for the decline in transportation costs over time. The residuals from this regression provide the factor-endowment corrected measure of trade Openness. Since Openness is a measure of trade openness and not trade protection, we expect the signs of the coefficients of our independent variable (labor-specificity) and control variables to be reversed in models where Openness is the dependent variable. To save space, we present below the results from $\Delta$ import duties and the change in the Hiscox-Kastner measure of trade protection. Results from tests using Leamer's (1988) measure and $\Delta$ tariff revenue are reported in the online appendix.

Before describing how we operationalized the independent variable, we briefly discuss the correla-

${ }^{19} \Delta_{i k t}^{2}=\left(\left(E_{i k t}-E_{k t}^{*}\right) / E_{k t}^{*}\right)^{2}\left[\Delta_{i l t}^{2}=\left(\left(E_{i l t}-E_{l t}^{*}\right) / E_{l t}^{*}\right)^{2}\right]$ where $E_{i k t}$ $\left(E_{i l t}\right)$ is the endowment of factor $k$ and $l$ of country $i$ at $t$ and $E_{k t}$ $\left(E_{l t}\right)$ is the world effective endowment at $t$. tion patterns among different measures of the dependent variable in our sample. As shown in Table 2, the change in the Hiscox-Kastner measure is positively and strongly correlated with $\Delta$ import duties and $\Delta$ tariff revenue but negatively correlated with the endowment-corrected measure of trade openness. This is not surprising given that higher trade barriers captured by the Hiscox-Kastner measure will be positively correlated with greater trade protection and provide more tariff revenue for the government, but will be negatively correlated with the degree of trade openness as measured by Openness. In addition, the correlation between $\Delta$ import duties and $\Delta$ tariff revenue also is positive and strong in both samples, while the correlation between $\Delta$ import duties and Openness is negative. These patterns also are expected since higher import duties will generate more tariff revenue for the government, but will act as a barrier to greater trade openness. In short, the different measures of the dependent variable are highly correlated in expected directions, therein indicating the underlying consistency across these measures.

Next, we operationalize our independent variable-the extent of intersectoral labor specificity (i.e., the lack of intersectoral labor mobility) in tradable sectors-for each country-year. We focus on intersectoral labor specificity for two reasons. First, our formal model specifically analyzes how labor specificity in tradable sectors affects trade protection in majoritarian democracies. Second, as described below, a key advantage of our "structural" measures of labor specificity is that they build on partial-adjustment theory in labor economics which predicts that nominal rigidities in the labor market impede intersectoral labor mobility (see Hamermesh 1990; Nickell 1985). Since the formal model considers the impact of these rigidities on labor specificity, our empirical indicators of labor specificity allow us to directly test our model's implication. Measuring intersectoral

\section{TABLE 2 Correlation Matrix of Measures of the Dependent Variable}

\begin{tabular}{lcccc}
\hline & \multicolumn{5}{c}{$\begin{array}{c}\text { Change in } \\
\text { Hiscox- }\end{array}$} \\
Majoritarian & $\begin{array}{c}\Delta \text { Import } \\
\text { Suties }\end{array}$ & Revenue & $\begin{array}{c}\text { Kastner } \\
\text { Measure }\end{array}$ & Openness \\
\hline Import duties & 1.00 & & & \\
$\Delta$ Tariff Revenue & .672 & 1.00 & & \\
Change in & .590 & .451 & 1.00 & \\
$\quad$ Hiscox-Kastner & & & & \\
Openness & -.376 & -.402 & -.488 & 1.00 \\
\hline
\end{tabular}


labor specificity is difficult. We use two measures for the degree of labor specificity in each country (see e.g., Hiscox and Rickard 2002; Wacziarg and Wallack 2004). Both of these measures are structural since they are based on data that capture labor mobility (or lack thereof) over time across five main tradable sectors, as classified by the International Labor Organization (ILO) and United Nations Industrial (UNIDO): (1) Agriculture and Hunting, (2) Forestry and Fisheries, (3) Mining and Quarrying, (4) Manufacturing, and (5) Transportation and Warehousing. ${ }^{20}$

Our first measure of labor specificity captures two effects in the labor market: direct movement of workers from one sector to another and sectorally differentiated changes in aggregate employment (resulting from population growth and entry of individuals into the labor force after being unemployed). We label this measure as $\Delta$ Strucspecificity. It is operationalized as an index, which is developed as follows. First, following Wacziarg and Wallack (2004), we develop a measure that captures the absolute value of changes in the share $S_{s, i}^{t}$ of each sector $s$ in total employment for each country $i$ in any given year $t$, which is:

$$
\Delta \text { Shift }=0.5 \sum_{s}^{S}\left|S_{s, i}^{t}-S_{s, i}^{t-\delta}\right|
$$

We let $\delta=2$ years in the $\Delta$ Shift measure because meaningful shifts in intersectoral labor mobility typically occur in two years (Wacziarg and Wallack 2004). Further, setting $\delta=2$ ensures that the measure $\Delta$ Shift is not affected by business cycle effects. That said, setting $\delta=1$ or 3 years did not alter the results reported below. $\Delta$ Shift is bounded between 0 (no intersectoral labor mobility) and 1 (complete intersectoral mobility). Hence $\Delta$ Shift captures the change in intersectoral labor mobility. We then take the difference between 1 and $\Delta$ Shift to measure $\Delta$ Strucspecificity, which is also bounded between 0 and 1 . Higher values of $\Delta$ Strucspecificity indicate greater intersectoral labor specificity.

The second measure of labor specificity, labeled $\Delta$ Labor Specificity, focuses strictly on labor movement across sectors. $\Delta$ Labor Specificity is based on inverting a well-known measure of intersectoral labor mobility (see Wacziarg and Wallack 2004). It is developed as follows. First, intersectoral labor mobility in each country is computed by isolating the fraction of jobs that move from one sector to another independent of

\footnotetext{
${ }^{20} \mathrm{We}$ exclude the services sector from our labor specificity measures since Jensen and Keltzer (2005) suggest that services are in the nontradable sector, thus not applicable to our study.
}

overall employment gains or losses. Let $E_{S, i}^{t}$ denote employment in sector $S$ in country $i$ at time $t$. Hence

$$
\begin{aligned}
& \Delta \text { Labor Mobility }= \\
& \frac{\sum_{s}^{S}\left|E_{S, i}^{t}-E_{S, i}^{t-\delta}\right|-\left|\sum_{s}^{S} E_{S, i}^{t}-\sum_{s}^{S} E_{S, i}^{t-\delta}\right|}{\frac{1}{2} \sum_{S}^{S}\left(E_{S, i}^{t}+E_{S, i}^{t-\delta}\right)}
\end{aligned}
$$

The difference in the numerator between the term on the left and the term on the right gives the employment changes that result from pure shifts of jobs across different sectors in the economy. The denominator computes the average of total employment for the sectors in consideration between $t$ and $t-\delta$. As before, we let $\delta=2$ years to capture meaningful shifts in intersectoral labor mobility and to minimize the effects of business cycle shocks. Setting $\delta=1$ or 3 years did not alter the results reported for this measure below. We simply use the inverse of $\Delta$ Labor Mobility to convert it to a measure of intersectoral labor specificity. Our second measure is thus $\Delta$ Labor Specificity $=1 / \Delta$ Labor Mobility. From Hypothesis 1 , we expect that the two measures of labor specificity will have a positive and significant effect on the change in trade protection in majoritarian democracies. Data for our measures of labor specificity are from International Labor Organization database (ILO, 2005) and the United Nations Industrial Development Organization industrial statistics datasets (UNIDO, 2003).

We control for political and economic variables identified by the literature as important determinants of trade protection. With respect to political controls, we follow Milner and Judkins (2004) and include Presidential Democracy and Federal as dummies that represent countries with presidential and federal systems, respectively. We also include Government Partisanship that is coded on a $0-2$ scale with 0 representing right governments and 2 left governments. Data for these three variables are from the World Bank's Database of Political Institutions (DPI; Beck et al. 2001). Milner and Judkins (2004) claim that the presidential system is more favorable to free trade, while left governments and federal systems are more protectionist. We expect Presidential Democracy to be negative, but Government Partisanship and Federal will be positive.

We include Taagepera and Shugart's (1989) measure of Effective Number of Legislative Parties (ENLP) since Nielson $(2003,475)$ claims that greater party fragmentation in the legislature leads to increased trade protection. Although the literature is divided over the issue of whether or not more veto 
players in government leads to higher trade protection (see Henisz and Mansfield 2006; Milner, Mansfield, and Pevehouse 2007), we include Veto Players using data from the World Bank's DPI (Beck et al. 2001). McGillivray (2004) and Hankla (2006) suggest that countries with strong political parties (i.e., party leaders exercise a high degree of control over party nominations) will produce freer trade policies. Based on Carey and Shugart's (1995) classification, we measure Party Strength on a 0-2 scale with 0 indicating low party strength and 2 denotes high party strength. Party Strength should have a negative effect.

With respect to the economic variables, we include log (GDP per capita) and log (Population) since trade protection may be affected by per capita income and a country's overall size. We also control for the change in each country's real effective exchange rate ( $\Delta$ Real eff exch rate) that is expected to increase trade barriers and a change in the terms of trade ( $\Delta$ terms of trade) that will have a negative effect on the dependent variable. Data for these variables are from the IMF's Government Financial Statistics and the World Bank's WDI (2003). Busch and Reinhardt (1999) suggest that trade barriers are likely to be higher in countries where production is geographically concentrated. We operationalize an index of "adjusted geographic concentration" based on a study by Spiezia (2003) and label this measure as $A G C$ index $=$ GC/GC ${ }^{M a x}$. The AGC index is a continuous measure that ranges from 0 (low) to 1 (high geographic concentration of production). Data for the $A G C$ index are from Spiezia (2003) and GTAP (2006). Since Adsera and Boix (2002) suggest that public expenditure or the size of the public sector may influence the degree of trade openness, we control for Government Spending that is measured as the percent of central government expenditure over GDP. Following Milner and Judkins (2004, 106), we include Transportation Costs - operationalized using cif to fob ratios supplemented with shipping costs-as a proxy for globalization since globalization may force countries to lower trade barriers. Data for this variable is from the IMF's (2004) Direction of Trade Statistics and Hummels and Lugovskyy (2006).

To account for each country's relative factor endowments in the specification, we introduce the $\log$ of capital-labor ratio. Data for labor is from the Penn World Tables (2004) and capital from Przeworski et al. (2000). Recent studies suggest that the educational attainment of workers affects trade policy preferences, which consequently affects trade protection (Baker 2005; Mayda and Rodrik 2005; Scheve and Slaughter 2001). Therefore, we include from
Barro and Lee (2000) and the World Bank's WDI (2003) the percent of the population over age 15 that has completed secondary education in each country as a proxy for educational attainment (Education). Scholars debate whether or not the GATT and its successor, the WTO have successfully reduced trade barriers (Rose 2004a; Tomz, Goldstein, and Rivers 2007). We introduce the dummy variable GATT/ WTO that is coded as 1 for countries that are formal members of the GATT (until 1995) and then the WTO after 1995. Since the size of the agricultural sector may affect trade protection (Thies and Porche 2007), we control for the size of each country's agricultural sector as a percent of GDP (Agriculture $\%$ of $G D P$ ). Finally, since the degree of unemployment benefits available to workers may influence their incentives to remain specific (Estevez-Abe, Iverson, and Soskice 2001), we control for Unemployment Benefits (as \% of GDP). Data are from the International Social Security Association (2004) Social Security Programs, Vodopivec (2004), and GTAP (2006).

We estimate TSCS regression models with panelcorrected standard errors (PCSE's) that correct for heteroskedasticity and contemporaneous correlation. Country fixed effects are included in each model. To account for serial correlation, we include the lagged dependent variable in the TSCS models (Beck and Katz 1995). For robustness tests, we estimate the TSCS models via the Prais-Winsten procedure with PCSE's, fixed effects, and an AR (1) parameter, but exclude the lagged dependent variable. The results remain robust, though they are not reported here to conserve space. We also check the validity of our results by estimating some system Generalized Methods of Moment (GMM) models that account for potential endogeneity between labor specificity and each measure of trade protection used here.

\section{Results}

Table 3 reports the results from models that are estimated with a lagged dependent variable, PCSE's, and fixed effects and where the dependent variable is $\Delta$ import duties. Models 1, 2, and 3 use $\Delta$ Strucspecificity as the key independent variable for three different samples (all, OECD, and non-OECD majoritarian democracies), while models 4 , 5, and 6 use $\Delta$ Labor Specificity as the key independent variable for the three samples.

For the entire sample of majoritarian democracies, the coefficient of $\Delta$ Strucspecificity has the predicted 
TABLE 3 Effect of Labor Mobility on Change in Import Duties in Majoritarian Democracies

\begin{tabular}{|c|c|c|c|c|c|c|}
\hline & \multicolumn{3}{|c|}{$\Delta$ Strucspecificity $[0]$} & \multicolumn{3}{|c|}{$\Delta$ Labor specificity } \\
\hline & All Model 1 & OECD Model 2 & non-OECD Model 3 & All Model 4 & OECD Model 5 & non-OECD Model 6 \\
\hline Lagged DV & $.1254^{\star \star \star}(.0433)$ & $.1170^{\star \star \star}(.0401)$ & $.1240^{\star \star \star}(.0345)$ & $.1615^{\star \star \star}(.0410)$ & $.2155^{\star \star \star}(.0321)$ & $.1246^{\star \star \star}(.0340)$ \\
\hline$\Delta$ Strucspecificity & $.2429^{\star \star \star}(.0701)$ & $.2725^{\star \star *}(.0442)$ & $.4155^{\star \star \star}(.0318)$ & & & \\
\hline$\Delta$ Labor specificity & & & & $.4314^{\star \star \star}(.0892)$ & $.3114^{\star * *}(.0442)$ & $.5234^{\star * \star}(.1018)$ \\
\hline Ln(GDP per capita) & $-.0941(.0829)$ & $-.0863(.1384)$ & $-.0797^{\star \star \star}(.0255)$ & $-.0939(.0855)$ & $-.0657(.1071)$ & $-.0563^{\star * *}(.0134)$ \\
\hline Education & $-.0379(.0701)$ & $-.0483(.0806)$ & $.0571(.0925)$ & $-.0287(.0460)$ & $-.0312(.0532)$ & $.0260(.0325)$ \\
\hline Ln(Population) & $.0106(.0332)$ & $.0236(.0232)$ & $.0139(.0119)$ & $.0202(.0343)$ & $.0133(.0255)$ & $.0158(.0124)$ \\
\hline AGC Index & $.0125(.0261)$ & $.0770^{\star * *}(.0244)$ & $.0697(.0521)$ & $.0137(.0225)$ & $.0621^{\star * *}(.0215)$ & $.0590(.0322)$ \\
\hline$\Delta$ Real eff exch rate & $.0137^{\star * *}(.0052)$ & $.0752(.0937)$ & $.0814^{\star * \star}(.0308)$ & $.0139^{\star * \star}(.0050)$ & $.0481(.0709)$ & $.0755^{\star \star \star}(.0218)$ \\
\hline Ln(Capital/Labor) & $.0125(.0261)$ & $-.0432^{\star * *}(.0124)$ & $.0298(.0377)$ & $.0119(.0182)$ & $-.0588^{\star \star *}(.0235)$ & $.0312(.0406)$ \\
\hline Govt. spending & $.0554(.1107)$ & $.0651(.1432)$ & $.0326(.0717)$ & $.0822(.1233)$ & $.0467(.1236)$ & $.0317(.0499)$ \\
\hline$\Delta$ Terms of Trade & $-.0146^{\star * *}(.0050)$ & $-.0251^{\star *}(.0103)$ & $-.0797^{\star \star *}(.0255)$ & $-.0165^{\star \star \star}(.0043)$ & $-.0182^{\star * \star}(.0061)$ & $-.0353^{\star * \star}(.0095)$ \\
\hline GATT/WTO & $-.0110(.0463)$ & $-.0137^{\star * *}(.0041)$ & $.0114(.0234)$ & $-.0163(.0384)$ & $-.0160^{* * *}(.0035)$ & $.0136(.307)$ \\
\hline Party Strength & $-.0252(.0177)$ & $-.0461(.0435)$ & $-.0859(.0801)$ & $-.0812(.0971)$ & $-.0231(.0646)$ & $-.0344(.0625)$ \\
\hline Veto Players & $-.0147(.0254)$ & $-.0565(.0618)$ & $-.1143(.1652)$ & $-.0238(.0145)$ & $-.0414(.0568)$ & $-.1210(.1044)$ \\
\hline Partisanship & $.0101(.0096)$ & $.0152^{\star * *}(.0047)$ & $.0736(.0761)$ & $.0109(.0088)$ & $.0204^{\star * *}(.0045)$ & $.0526(.0391)$ \\
\hline Presidential & $-.0179(.1642)$ & $-.0354(.0742)$ & $.0211(.5340)$ & $-.0179(.1605)$ & $-.0311(.0722)$ & $.0481(.4199)$ \\
\hline Federal & $.0009(.0307)$ & $.0003(.0508)$ & $.0072(.0341)$ & $.0012(.0198)$ & $.0006(.0327)$ & $.0061(.0416)$ \\
\hline ENLP & $.0379(.0701)$ & $.0406(.0565)$ & $.0299(.0511)$ & $.0216(.0599)$ & $.0412(.0319)$ & $.0297(.0218)$ \\
\hline Transportation costs & $-.0089(.0074)$ & $-.0075(.0083)$ & $-.0090(.0097)$ & $-.0099(.0116)$ & $-.0083(.0091)$ & $-.0095(.0108)$ \\
\hline agriculture(\%GDP) & $.0216(.0599)$ & $.0307(.0512)$ & $.0249(.0634)$ & $.0115(.0152)$ & $.0226(.0165)$ & $.0317(.0294)$ \\
\hline Unemployment benefit (\%GDP) & $.0115(.0132)$ & $.0122(.0128)$ & $.0173(.0139)$ & $.0121(.0135)$ & $.0111(.0143)$ & $.0132(.0128)$ \\
\hline Constant & $.1073^{\star * \star}(.0051)$ & $.1155^{\star * *}(.0048)$ & $.1303^{\star * *}(.0118)$ & $.1409^{\star * *}(.0090)$ & $.1204^{\star * *}(.0067)$ & $.1326^{\star * \star}(.0098)$ \\
\hline Adjusted $\mathrm{R}^{2}$ & .317 & .399 & .324 & .328 & .407 & .305 \\
\hline$N$ & 411 & 152 & 259 & 411 & 152 & 259 \\
\hline
\end{tabular}

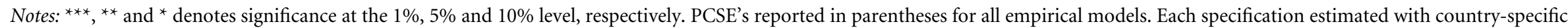
fixed effects ("fe"). 
positive sign and is significant at the $1 \%$ level in model 1, while the effect of $\Delta$ Labor Specificity is also positive and highly significant in model 4 . These results provide strong statistical support for Hypothesis 1. Substantively, we find that when $\Delta$ Strucspecificity rises by one standard deviation above its mean and other variables in model 1 are held at their means, the dependent variable $\Delta$ import duties increases by approximately $6 \%$. This substantive effect is illustrated in Figure 2. Relative to the sample mean of $\Delta$ import duties (4\%), this substantive effect is large.

For both OECD and non-OECD samples, the coefficients of $\Delta$ Strucspecificity and $\Delta$ Labor Specificity remain positive and significant at the $1 \%$ level in the relevant models. The substantive effects for both measures of labor specificity are consistent with earlier findings. For example, when $\Delta$ Strucspecificity increases by one standard deviation above its mean, holding other variables constant, $\Delta$ import duties rises by $7 \%$ and $10 \%$, respectively.

Due to space constraints, we briefly discuss the results for the control variables in Table 3 . The effect of Government Partisanship is insignificant in the full sample of majoritarian democracies and the subsample of non-OECD majoritarian countries, but is positive and highly significant in the sample of OECD majoritarian democracies. This supports Milner and Judkins's (2004) finding that left-leaning governments are more likely to protect the economy by raising tariffs in OECD countries. The effects of Presidential Democracy, Federal, Veto Players, Party Strength, and ENLP are, however, each insignificant in the models in Table 3 . These results should not be taken to suggest that these political factors do not

\section{FIGURE 2 Effect of $\Delta$ Strucspecificity on $\Delta$ Import Duties in majoritarian democracies}

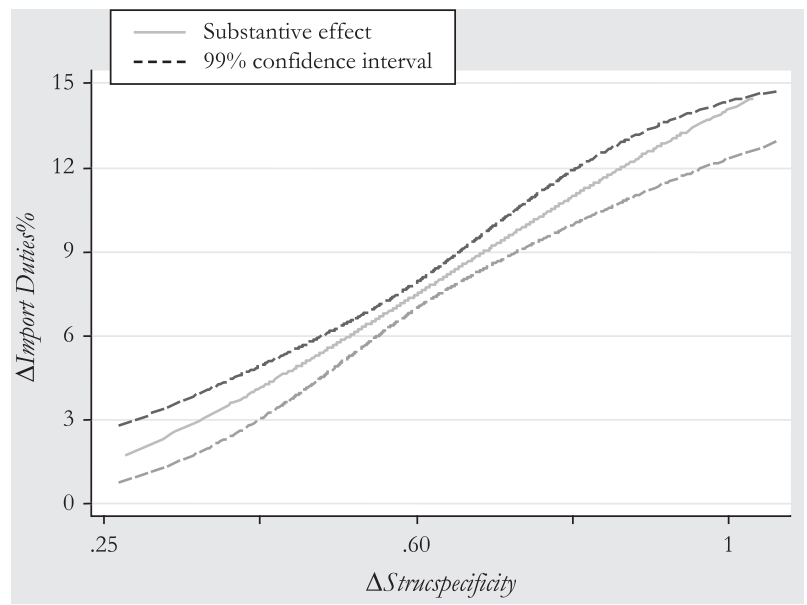

influence trade protection. Unlike existing studies of trade protection, our sample is restricted to majoritarian democracies for the specific purpose of testing Hypothesis 1. The restrictive nature of our sample may weaken the results for some of the political control variables. In addition, in contrast to extant studies, we use the change of trade protection rather than its level as our dependent variable. Since temporal variations in political and institutional variables are low, it is not surprising that temporally invariant political variables have little effect on the change in trade protection, even though they are shown to influence the level of trade protection (e.g., Hankla 2006; McGillivray 2004).

Turning to the economic control variables, we find that $\log$ (Population), Transportation Costs, Government Spending, Agriculture (\% of GDP), and Unemployment Benefits (\% of GDP) each have insignificant effects in the models in Table 3. The change in Real Effective Exchange Rate is positive and significant in the full sample as expected, while the change in Terms of Trade is negative and significant as predicted in each model. The AGC index is positive and significant for the models estimated for the sample of OECD majoritarian democracies. This supports Busch and Reinhardt's (1999) claim that higher geographic concentration of production leads to an increase in trade protection in advanced OECD democracies. The estimate of $\log$ of capital-labor ratio is negative and significant in the sample of OECD majoritarian democracies. This fits well with the prediction of the Heckscher-Ohlin model. The GATT/WTO dummy is insignificant in the global and non-OECD sample, but is negative and significant in the OECD sample.

\section{Robustness Tests}

Will the results in Table 3 hold with respect to alternative measures of the dependent variable? To answer this question, we estimate the effects of $\Delta$ Strucspecificity and $\Delta$ Labor Specificity on the change in the Hiscox-Kastner measure of trade protection in the three samples. As reported in Table 4, the effects of both $\Delta$ Strucspecificity and $\Delta$ Labor Specificity are positive and significant at the $1 \%$ level in all three samples for the Hiscox-Kastner measure.

We also check the effects of $\Delta$ Strucspecificity and $\Delta$ Labor Specificity on two additional measures of the dependent variable, namely, $\Delta$ tariff revenue and Leamer's endowment-corrected measure of trade 
TABle 4 Effect of Labor Mobility on Change in Hiscox-Kastner Measure of Trade Protection in Majoritarian Democracies

\begin{tabular}{|c|c|c|c|c|c|c|}
\hline & \multicolumn{3}{|c|}{$\Delta$ Strucspecificity } & \multicolumn{3}{|c|}{$\Delta$ Labor specificity } \\
\hline & All Model 7 & OECD Model 8 & non-OECD Model 9 & All Model 10 & OECD Model 11 & non-OECD Model 12 \\
\hline Lagged DV & $.1702^{\star * \star}(.0401)$ & $.2104^{\star \star \star}(.0618)$ & $.2039^{\star * \star}(0.0614)$ & $.2064^{\star * \star}(.0492)$ & $.1233^{\star * *}(.0427)$ & $.2122^{\star \star \star}(.0709)$ \\
\hline$\Delta$ Strucspecificity & $.2980^{\star * *}(.0972)$ & $.3790^{\star * *}(.1161)$ & $.2543^{\star * \star}(.0851)$ & & & \\
\hline$\Delta$ Labor specificity & & & & $.2044^{\star * \star}(.0649)$ & $.2925^{\star \star \star}(.0872)$ & $.1541^{\star \star \star}(.0603)$ \\
\hline Ln(GDP per capita) & $-.0147(.0254)$ & $-.0361(.0215)$ & $-.0417^{\star \star \star}(.0108)$ & $-.0271(.0219)$ & $-.0167(.0102)$ & $-.0340^{\star * \star}(.0115)$ \\
\hline Education & $-.0295(.0762)$ & $-.0526(.0497)$ & $.0037^{\star \star \star}(.0016)$ & $-.0130(.0449)$ & $-.0225(.0170)$ & $.0089^{\star \star}(.0045)$ \\
\hline Ln(population) & $.0472(.0892)$ & $.0749(.0656)$ & $.0171(.0149)$ & $.0216(.0599)$ & $.0307(.0512)$ & $.0182(.0180)$ \\
\hline AGC Index & $.0112(.0319)$ & $.0322(.0293)$ & $.0199(.0435)$ & $.0319(.0253)$ & $.0371(.0242)$ & $.0153(.0240)$ \\
\hline$\Delta$ Real eff exch rate & $.0126(.0543)$ & $.0155(.0231)$ & $.0396(.0450)$ & $.0101(.0096)$ & $.0150(.0147)$ & $.0258(.0319)$ \\
\hline Ln(Capital/Labor) & $.0116(.0191)$ & $-.0225^{\star * \star}(.0063)$ & $.0170^{\star \star \star}(.0081)$ & $.0133(.0182)$ & $-.0288^{\star * *}(.0095)$ & $.0193^{\star * \star}(.0067)$ \\
\hline$\Delta$ Terms of Trade & $-.0279(.0382)$ & $-.0108(.0477)$ & $-.0039^{\star *}(.0016)$ & $-.0118(.0176)$ & $-.0253(.0441)$ & $-.0075^{\star *}(.0029)$ \\
\hline GATT/WTO & $-.0173(.0193)$ & $-.0140^{\star \star \star}(.0038)$ & $.0125(.0143)$ & $-.0136(.0154)$ & $-.0122^{\star * \star}(.0041)$ & $.0119(.0166)$ \\
\hline Govt. spending & $.0336(.0229)$ & $.0539(.0616)$ & $.0126(.0130)$ & $.0429(.0371)$ & $.0530(.0324)$ & $.0218(.0175)$ \\
\hline Party Strength & $-.0415(.0721)$ & $-.0372(.0198)$ & $-.0162(.0739)$ & $-.0526(.0417)$ & $-.0240(.0181)$ & $-.0153(.0546)$ \\
\hline Vto Players & $.0153(.0818)$ & $.0210(.0637)$ & $.0136(.0151)$ & $.0121(.0755)$ & $.0311(.0245)$ & $.0129(.0136)$ \\
\hline Partisans ip & $.0072(.0150)$ & $.0119^{\star \star *}(.0046)$ & $.0048(.0039)$ & $.0065(.0134)$ & $.0098^{\star * *}(.0031)$ & $.0033(.0021)$ \\
\hline Presidential & $-.0379(.0701)$ & $-.0283(.0806)$ & $.0104(.0499)$ & $-.0433(.0681)$ & $-.0179(.0624)$ & $.0082(.0421)$ \\
\hline Federal & $.0054(.0107)$ & $.0063(.0084)$ & $.0094(.0133)$ & $.0041(.0087)$ & $.0059(.0072)$ & $.0107(.0112)$ \\
\hline ENLP & $.0125(.0261)$ & $.0233(.0304)$ & $.0065(.1361)$ & $.0045(.0133)$ & $.0251(.0087)$ & $.0089(.0141)$ \\
\hline transportation costs & $-.0040(.0086)$ & $-.0029(.0018)$ & $-.0019(.0021)$ & $-.0014(.0026)$ & $-.0013(.0015)$ & $-.0012(.0013)$ \\
\hline Agriculture(\%GDP) & $.0711(.0605)$ & $.0742(.0662)$ & $.0422(.0548)$ & $.0586(.0611)$ & $.0637(.0433)$ & $.0287(.0247)$ \\
\hline Unemployment benefit (\%GDP) & $.0125(.0261)$ & $.0433(.0304)$ & $.0669(.0498)$ & $.0160(.0136)$ & $.0126(.0185)$ & $.0133(.0187)$ \\
\hline Constant & $.6051^{\star * \star}(.0735)$ & $.8077^{\star \star *}(.0642)$ & $.4155^{\star * *}(.0292)$ & $.4287^{\star * *}(.0450)$ & $.6322^{\star * *}(.0242)$ & $.3128^{\star \star \star}(.0192)$ \\
\hline Adjusted $\mathrm{R}^{2}$ & .226 & .214 & .197 & .258 & .229 & .178 \\
\hline$N$ & 411 & 152 & 259 & 411 & 152 & 259 \\
\hline
\end{tabular}

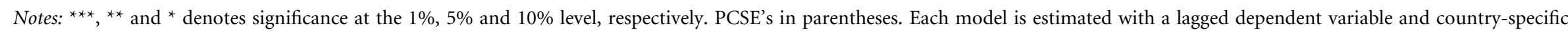
fixed effects. 
Openness. The results for these two measures are reported in two tables in the online appendix. In both tables, $\Delta$ Strucspecificity and $\Delta$ Labor Specificity have the predicted significant effects in all three samples.

We check the econometric validity of our results by conducting two tests to address the concern that our measures of labor specificity may be endogenous to trade protection, even though there is little econometric evidence for such a possibility at the aggregate level (see Wacziarg and Wallack 2004). We first conduct a variant of the Granger causality test designed for panel data (Hurlin and Venet 2003) to assess the potential endogeneity problem. The results from these tests indicate that intersectoral labor specificity is not endogenous to change in import duties or other measures of the dependent variable. ${ }^{21}$ We further address the possibility of endogeneity by implementing the dynamic panel estimatorthe Generalized Method of Moments (GMM) suggested by Arellano and Bond (1991) and Blundell and Bond (1998). The GMM estimator corrects for endogeneity by using moment conditions to derive a set of valid instruments for our endogenous explanatory variables. It also addresses the possibility of serial correlation and allows us to control for country fixed effects and heteroskedasticity via White's heteroskedasticity consistent standard errors. We follow Blundell and Bond's (1998) advice and estimate what they term a "system GMM" model that involves estimation of a single system that combines a regression in first differences and a regression in levels. The instruments for the regression in first differences are lagged levels (dated $t-2$ ) of the endogenous explanatory variables, while the instruments for the regression in levels are the lagged differences of the endogenous explanatory variables. Blundell and Bond (1998) show that estimating the two equations (levels and differences) in a single system reduces the potential bias and imprecision associated with just the first-difference GMM estimator.

In separate system GMM models, we estimate the impact of labor specificity on $\Delta$ import duties and the change in the Hiscox-Kastner trade protection measure for the three samples. We report results from the levels regression in the system GMM model for the sample of all majoritarian countries in Table 5 and the results for the other two samples in Table 6.

\footnotetext{
${ }^{21}$ Granger causality tests indicate that we cannot reject the null that $\Delta$ importduties does not cause $\Delta$ Strucspecificity, $\mathrm{p}=.67$ $(\mathrm{p}=.74)$ and $\Delta$ LaborSpecificity, $\mathrm{p}=.70(\mathrm{p}=.78)$. We obtain similar results from the Granger causality for other measures of trade protection including the change in the Hiscox-Kastner measure and change in tariff revenues.
}

In Table 5, the effects of both measures of labor specificity, i.e., $\Delta$ Strucspecificity and $\Delta$ Labor Specificity, remain positive and highly significant in the system GMM models for the sample of all majoritarian democracies irrespective of whether we use $\Delta$ import duties or the change in the Hiscox-Kastner measure as the dependent variable. Further, as reported in Table 6, the effects of the two measures of labor specificity are positive and highly significant in the system GMM models for the samples of OECD and non-OECD majoritarian democracies, regardless of whether simport duties or the change in the Hiscox-Kastner measure is the dependent variable. These results confirm Hypothesis 1 even after correcting for potential endogeneity.

As a final robustness exercise, we estimated all the models with additional control variables: Industry value added/GDP, Ln (land-labor) ratio, average district magnitude and individual characteristics such as Age and Female that may affect voters' incentives to remain specific. Age is the percent of the labor force above 60 years, while Female is the percent of the labor force that is female. Including these additional controls did not alter the statistical significance or substantive impact of the reported results. We also conducted some diagnostic tests of serial correlation, omitted variable bias and normality of the error terms for the empirical models, all of which suggest that the estimates are econometrically sound. ${ }^{22}$

\section{Conclusion}

In this article, we analyzed the impact of intersectoral labor (im)mobility (specificity) on the change in trade protection in majoritarian democracies. Our formal model predicts that an increase in intersectoral labor specificity leads to a rise in trade protection in majoritarian democracies. We find strong statistical support for this prediction in three separate samples (all, OECD, and non-OECD majoritarian countries). The empirical results also remain robust when we control for alternative explanations, apply different estimation techniques, and use different measures of trade protection.

\footnotetext{
${ }^{22}$ The Breusch-Godfrey Lagrange Multiplier test fails to reject the null of no autocorrelation in each lagged dependent variable model. The Arellano-Bond test for autocorrelation in first differences in the GMM models fail to reject the null that the error term is not serially correlated. The RESET test for each model rejects the null that each estimated model is misspecified. The Jarque-Bera indicates that the residuals approximate a normal distribution.
} 
TABle 5 Effect of Labor Mobility on Change in Trade Protection in All Majoritarian Democracies

\begin{tabular}{|c|c|c|c|c|}
\hline \multirow[b]{2}{*}{ GMM levels regression } & \multicolumn{2}{|c|}{ DV: $\Delta$ Import duties $_{i t}$} & \multicolumn{2}{|c|}{ DV: $\Delta$ Hiscox-Kastner measure } \\
\hline & Model 13 & Model 14 & Model 15 & Model 16 \\
\hline Lagged DV & $.106^{\star * \star}(.024)$ & $.115^{\star \star \star}(.036)$ & $.276^{\star * \star}(.086)$ & $.317^{\star \star \star}(.080)$ \\
\hline Strucspecificity & $.322^{\star * \star}(.095)$ & & $.342^{\star \star \star}(.060)$ & \\
\hline Labor Specificity & & $.405^{\star \star \star}(.106)$ & & $.254^{* * *}(.065)$ \\
\hline Ln(GDP per capita) & $-.044^{\star \star}(.021)$ & $-.029^{\star *}(.013)$ & $-0.062^{\star \star}(0.018)$ & $-0.044^{\star *}(0.003)$ \\
\hline Education & $-.102(.105)$ & $-.104(.144)$ & $-.186(.150)$ & $-.159(.363)$ \\
\hline Log(population) & $.377(.370)$ & $.259(.446)$ & $.422(.548)$ & $.386(.511)$ \\
\hline AGC Index & $0.086(0.090)$ & $0.072(0.084)$ & $0.059(0.048)$ & $0.067(0.061)$ \\
\hline Real exch rate. & $.030^{\star * *}(.009)$ & $.032^{\star \star *}(.010)$ & $0.080^{* *}(0.014)$ & $0.059^{* * *}(0.007)$ \\
\hline Ln(Capital/labor) & $.0149(.0121)$ & $.0214(.0143)$ & $.0203(.0140)$ & $.0312(.0252)$ \\
\hline Terms of Trade & $-0.140^{\star * \star}(0.039)$ & $-0.150^{\star * \star}(0.041)$ & $-0.137^{\star \star \star}(0.045)$ & $-.151^{\star * *}(0.049)$ \\
\hline GATT/WTO & $.043(.032)$ & $.035(.032)$ & $0.045(0.052)$ & $0.020(0.016)$ \\
\hline Govt. spending & $.043^{\star * \star}(.012)$ & $.033^{\star * \star}(.011)$ & $.015^{\star * \star}(.004)$ & $.017^{\star \star \star}(.004)$ \\
\hline Party Strength & $-.637(.433)$ & $-.287(.247)$ & $-.377(.370)$ & $-.259(.446)$ \\
\hline Veto Players & $0.015(0.030)$ & $0.014(0.055)$ & $0.018(0.041)$ & $0.026(0.088)$ \\
\hline Partisanship & $0.025(0.019)$ & $0.080(0.059)$ & $0.066(0.048)$ & $0.083(0.096)$ \\
\hline Presidential & $.008(.006)$ & $.006(.005)$ & $.013(.015)$ & $.075(.055)$ \\
\hline Federal & $.006(.0010)$ & $.007(.005)$ & $0.005(0.008)$ & $0.003(0.002)$ \\
\hline ENLP & $0.091(.0064)$ & $.0035(.0038)$ & $0.063(0.085)$ & $0.095(0.108)$ \\
\hline Transportation costs & $-.0037(.0070)$ & $-.0048(.0080)$ & $-.0030(.0027)$ & $-.0041(.0039)$ \\
\hline agriculture(\%GDP) & $.0328(.0286)$ & $.0374(.0277)$ & $.0711(.0506)$ & $.0589(.0802)$ \\
\hline Unemployment benefit (\%GDP) & $.016(.010)$ & $.012(.014)$ & $.012(.031)$ & $.022(.029)$ \\
\hline Constant & $.491^{\star \star \star}(.112)$ & $.400^{\star * \star}(.115)$ & $0.743^{\star * \star}(0.129)$ & $0.605^{\star * \star}(0.103)$ \\
\hline Adjusted $\mathrm{R}^{2}$ & .433 & .442 & .389 & .403 \\
\hline$N$ & 411 & 411 & 411 & 411 \\
\hline
\end{tabular}

Notes: ${ }^{* *},{ }^{* *}$ and ${ }^{*}$ denotes significance at the $1 \%, 5 \%$ and $10 \%$ level, respectively. Heteroskedastic-robust standard errors in parentheses. 
TABLE 6 Effect of Labor Mobility on Trade Protection in Separate Majoritarian Samples

\begin{tabular}{|c|c|c|c|c|c|c|c|c|}
\hline \multirow{3}{*}{$\begin{array}{l}\text { GMM levels } \\
\text { regression }\end{array}$} & \multicolumn{4}{|c|}{ OECD } & \multicolumn{4}{|c|}{ Non-OECD } \\
\hline & \multicolumn{2}{|c|}{ DV: Import duties it $_{\text {imp }}$} & \multicolumn{2}{|c|}{ DV: $\Delta$ Hiscox-Kastner measure } & \multicolumn{2}{|c|}{ DV: Import duties ${ }_{i t}$} & \multicolumn{2}{|c|}{ DV: $\Delta$ Hiscox-Kastner measure } \\
\hline & 17 & 18 & 19 & 20 & 21 & 22 & 23 & 24 \\
\hline Lagged DV & $.211^{\star * \star}(.049)$ & $.257^{\star * \star}(.043)$ & $.138^{\star \star \star}(.040)$ & $.182^{\star * \star}(.045)$ & $.251^{\star \star \star}(.096)$ & $.299^{* * *}(.083)$ & $.260^{\star * \star}(.064)$ & $.219^{\star \star}(.090)$ \\
\hline Strucspecificity & $0.284^{\star * *}(0.064)$ & & $0.397^{\star \star *}(0.074)$ & & $.309^{\star * \star}(.110)$ & & $.297^{\star \star \star}(.065)$ & \\
\hline Labor Specificity & & $0.362^{\star * *}(0.078)$ & & $0.341^{\star \star}(0.089)$ & & $.397^{\star \star \star}(.104)$ & & $.378^{\star \star \star}(.109)$ \\
\hline Ln(GDP per capita) & $-0.077(0.065)$ & $-0.186(0.164)$ & $-0.060(0.103)$ & $-0.163(0.085)$ & $-.047^{\star \star \star}(.015)$ & $-.051^{\star \star \star}(.019)$ & $-.044^{\star * \star}(.017)$ & $-.051^{\star \star \star}(.030)$ \\
\hline Education & $-0.036^{* *}(0.011)$ & $-0.029^{* *}(0.005)$ & $-0.044^{* * *}(0.003)$ & $-0.017^{\star \star \star}(0.003)$ & $.071(.073)$ & $.081(.067)$ & $.061(.119)$ & $.062(.110)$ \\
\hline $\operatorname{Ln}($ population) & $0.086(.0090)$ & $0.077(0.065)$ & $0.082(0.098)$ & $0.073(0.062)$ & $.088(.079)$ & $.081(.067)$ & $.054(.060)$ & $.040(.099)$ \\
\hline AGC & $0.175(0.174)$ & $0.195(0.187)$ & $0.113(0.124)$ & $0.146(0.153)$ & $.054(.060)$ & $.040(.110)$ & $.087(.063)$ & $.065(.125)$ \\
\hline Real exchange rate & $0.011^{\star * *}(0.002)$ & $0.017^{\star \star *}(0.006)$ & $0.049^{\star * \star}(0.0011)$ & $0.027^{\star * *}(0.0012)$ & $.095(.080)$ & $.097(.086)$ & $.058(.052)$ & $.052(.058)$ \\
\hline Ln(Capital/Labor) & $.041(.032)$ & $-.047^{\star \star \star}(.021)$ & $-.032^{\star * \star}(.014)$ & $.058(.049)$ & $.067(.032)$ & $.058(.052)$ & $.055(.053)$ & $.090(.068)$ \\
\hline Terms of Trade & $-.198(.178)$ & $-.145(.170)$ & $-.149(.116)$ & $-.125(.114)$ & $-.051^{\star * \star}(.020)$ & $-.088^{\star * \star}(.024)$ & $-.072^{\star * *}(.031)$ & $-.058^{\star *}(.029)$ \\
\hline GATT/WTO & $-0.028^{\star * *}(0.011)$ & $-0.023^{\star * \star}(0.008)$ & $-0.021^{\star * *}(0.009)$ & $-0.030^{\star * \star}(0.011)$ & $.031(.038)$ & $.036(.054)$ & $.017(.0061)$ & $.068(.083)$ \\
\hline Govt. spending & $-.032(.041)$ & $-.037(.038)$ & $-.025(.026)$ & $-.023(.018)$ & $-.098(.112)$ & $-.077(.090)$ & $-.086(.127)$ & $-.076(.114)$ \\
\hline Party Strength & $-0.101(0.060)$ & $-0.091(0.247)$ & $-0.103(0.112)$ & $-0.097(0.103)$ & $-.065(.097)$ & $-.044(.035)$ & $-.021(.063)$ & $-.035(.037)$ \\
\hline Veto Players & $-0.019(.0014)$ & $-.0035(.0038)$ & $-0.063(0.085)$ & $-0.095(0.108)$ & $-.021(.018)$ & $-.091(.080)$ & $-.023(.033)$ & $-.030(.029)$ \\
\hline Partisanship & $.012^{\star \star \star}(.004)$ & $.044^{\star * *}(.017)$ & $.090^{\star * *}(.022)$ & $.028^{\star * \star}(.004)$ & $.095(.080)$ & $.053(.071)$ & $.051(.069)$ & $.097(.038)$ \\
\hline Presidential & $-0.018(0.049)$ & $-0.031(0.020)$ & $-0.027(0.034)$ & $0.034(0.041)$ & $.017(.032)$ & $.019(.040)$ & $.010(.025)$ & $.012(.031)$ \\
\hline Federal & $-0.000(0.000)$ & $-0.000(0.001)$ & $-0.002(0.001)$ & $0.000(0.000)$ & $.023(.021)$ & $.021(.040)$ & $.043(.037)$ & $.047(.033)$ \\
\hline ENLP & $0.040(0.026)$ & $0.022(0.018)$ & $0.023(0.020)$ & $0.027(0.025)$ & $.027(.023)$ & $.022(.055)$ & $.051(.046)$ & $.046(.039)$ \\
\hline Transportation costs & $-.0375(.0701)$ & $-.0214(.0629)$ & $-.0231(.0339)$ & $-.0337(.0218)$ & $-.052(.041)$ & $-.047(.038)$ & $-.038(.060)$ & $-.052(.040)$ \\
\hline Agriculture(\%GDP) & $.0433(.0304)$ & $.0469(.0459)$ & $.0439(.0514)$ & $.0122(.0314)$ & $.603(.510)$ & $.524(.570)$ & $.371(.473)$ & $.581(.767)$ \\
\hline $\begin{array}{l}\text { Unemployment } \\
\text { benefit (\%GDP) }\end{array}$ & $.0226(.0597)$ & $.0212(.0517)$ & $.0216(.0199)$ & $.0327(.0433)$ & $.011(.0026)$ & $.0020(.0057)$ & $.0039(.0028)$ & $.0042(.0030)$ \\
\hline Constant & $.721^{\star * \star}(.106)$ & $.508^{\star \star \star}(.102)$ & $.472^{\star \star \star}(.085)$ & $.324^{\star \star \star}(.045)$ & $.194^{\star \star}(.018)$ & $.196^{\star \star}(.015)$ & $.165^{\star \star \star}(.056)$ & $.124^{\star * \star}(.061)$ \\
\hline Adjusted $\mathrm{R}^{2}$ & .533 & .542 & .511 & .537 & .242 & .280 & .279 & .311 \\
\hline$N$ & 203 & 203 & 203 & 203 & 411 & 411 & 411 & 411 \\
\hline
\end{tabular}

Notes: ${ }^{\star \star \star},{ }^{\star \star}$ and ${ }^{\star}$ denotes significance at the $1 \%, 5 \%$ and $10 \%$ level, respectively. Heteroskedastic-robust standard errors in parentheses. 
Our article offers both theoretical and empirical contributions to the literature on trade protection. In the trade politics literature, Mayer's (1984) theoretical model of trade policy has had an enormous impact (cited 296 times according to Google Scholar as of September 2007), but his model treats factor mobility as being dichotomous such that trade politics operates in two separate worlds-either Heckscher-Ohlin or Ricardo-Viner. Most ensuing work on trade politics has inherited the spirit of such a dichotomy. Recent theoretical and empirical work on factor mobility (Hiscox 2002; Wacziarg and Wallack 2004), however, demonstrated that factor mobility changes over time and across countries, generating varying implications for political coalitions and trade politics. We build on this recent work and construct a formal model of how the degree of labor specificity affects trade policy changes in majoritarian democracies. We believe that this analysis is the first in the literature that demonstrates both formally and empirically that intersectoral labor specificity has a significant impact on changes in trade protection in majoritarian democracies. The effect of labor specificity is empirically shown to be more robust than other existing explanations of trade policy, such as party strength, geographical concentration, veto players, political partisanship, and international trade institutions.

Unlike most existing studies on trade policy which focus almost exclusively on OECD democracies, we test the impact of intersectoral labor specificity on several measures of trade protection in a large data set that includes both OECD and non-OECD majoritarian democracies. Our empirical exercises significantly increase the generalizability of our findings. They also substantially extend the work by Hiscox (2002) who examines the impact of labor specificity, but only uses it to explain the type of political coalitions in six advanced industrial democracies. Moreover, instead of examining the level of trade protection, we focus on the change in trade protection, which helps control for the confounding impact of unobserved country characteristics and provides a more rigorous test of the underlying causal mechanism.

Our analysis offers two lessons to policy makers in majoritarian democracies. Those interested in reducing trade barriers should adopt policies that decrease nominal labor market rigidities, thus improving intersectoral labor mobility. In addition, while promoting free trade, governments should invest in assistance programs that help workers with their adjustment costs, since such programs make it less costly for workers to move across sectors and may therefore mitigate political opposition to free trade.

\section{Acknowledgments}

Earlier versions of this manuscript were presented at Vanderbilt University, Washington University and at the 2006 annual meeting of the Midwest Political Science Association. This manuscript has greatly benefited from the comments of the reviewers, John Geer, Mark Kayser, Daniel Kono, Burt Monroe, Eric Reinhardt, Stephanie Rickard, and seminar participants at Vanberbilt University, Washington University, and the 2006 Midwest Political Science Association meeting. The authors thank Sergio Bejar and Daehee Bak for research assistance. Mukherjee thanks the Neihaus Center for Globalization and Governance at Princeton University for research support. The usual disclaimer applies.

Manuscript submitted 6 June 2006

Manuscript accepted for publication 20 February 2008

\section{References}

Adsera, A., and Carles Boix. 2002. "Trade, Democracy and the Size of the Public Sector: The Political Underpinnings of Openness." International Organization 56 (2): 229-62.

Arellano, Manuel, and Stephen Bond. 1991. "Some Tests of Specification for Panel Data: Monte Carlo Evidence and an Application to Employment Equations." Review of Economic Studies 58 (2): 277-98.

Baker, Andy. 2005. "Who Wants to Globalize? Consumer Tastes and Labor Markets in a Theory of Trade Policy Beliefs." American Journal of Political Science 49 (4): 924-38.

Barro, Robert J., and Jong-Wha Lee. 2000. "International Data on Educational Attainment: Updates and Implications." NBER Working Paper No. W7911.

Beck, Nathaniel, and Jonathan Katz. 1995. "What to Do (and Not to Do) with Time-Series Cross-Section Data." American Political Science Review 89 (3): 634-47.

Beck, Thorsten, George Clarke, Alberto Groff, Philip Keefer, and Patrick Walsh. 2001. "New Tools and New Tests of Comparative Political Economy: The Database of Political Institutions." World Bank Economic Review 15 (1): 165-76.

Blais, André, and Marc André Bodet. 2006. "Does Proportional Representation Foster Closer Congruence between Citizens and Policymakers?" Comparative Political Studies 39 (10): 1243-62.

Blanchard, Olivier, and Justin Wolfers. 2000. "The Role of Shocks and Institutions in the Rise of European Unemployment: the Aggregate Evidence." Economic Journal 110 (3): 1-33.

Blanchard, Oliver, and Lawrence Katz. 1997. "What We Know and Do Not Know About the Natural Rate of Unemployment." Journal of Economic Perspectives 11 (1): 51-73.

Blundell, Richard W., and Stephen R. Bond. 1998. "Initial Conditions and Moment Restrictions in Dynamic Panel Data Models." Journal of Econometrics 87 (1): 115-43.

Busch, Marc L., and Eric Reinhardt. 1999. "Industrial Location and Protection: The Political and Economic Geography of 
U.S. Non-tariff Barriers." American Journal of Political Science 43 (4): $1028-50$.

Carey, John, and Matthew S. Shugart. 1995. "Incentives to Cultivate a Personal Vote: A Rank Ordering of Electoral Formula." Electoral Studies 14 (4): 417-39.

Cox, Gary W. 1990. "Centripetal and Centrifugal Incentives in Electoral Systems." American Journal of Political Science 31 (1): 82-108.

Dutt, Pushan, and Devashish Mitra. 2005. "Political Ideology and Endogenous Trade Policies: An Empirical Investigation." Review of Economics and Statistics 87 (1): 59-72.

Estevez-Abe, Margarita, Torben Iverson, and David Soskice. 2001. "Social Protection and the Formation of Skills." In Varieties of Capitalism: The Institutional Foundations of Comparative Advantage, ed. Peter A. Hall and David Soskice. New York: Oxford University Press, 145-83.

Ehrlich, Sean. 2007. "Access to Protection: Domestic Institutions and Trade Policies in Democracies." International Organization 61 (3): 571-606.

Frieden, Jeffrey. 1991. "Invested Interests: The Politics of National Economic Policies in a World of Global Finance." International Organization 45 (4): 425-51.

Global Trade Analysis Project. 2006. GTAP 6 Data Package. 3 CD-ROMS.

Golder, Matt. 2004. "Democratic Electoral Systems around the World.” Electoral Studies 24 (1): 103-21.

Grossman, Gene, and Elhanan Helpman. 2005. "Protectionist Bias in Majoritarian Politics." Quarterly Journal of Economics 120 (4): 1239-82.

Hamermesh, Daniel S. 1990. "Aggregate Employment Dynamics and Lumpy Adjustment Costs." Carnegie-Rochester Conference Series on Public Policy, Elsevier 33: 93-129.

Hankla, Charles. 2006. "Party Strength and International Trade: A Cross-National Analysis." Comparative Political Studies 39 (9): 1133-56.

Henisz, Witold J., and Edward D. Mansfield. 2006. "Votes and Vetoes: The Political Determinants of Commercial Openness." International Studies Quarterly 50 (1): 189-211.

Hiscox, Michael J. 2002. International Trade and Political Conflict: Commerce, Coalitions and Mobility. Princeton, NJ: Princeton University Press.

Hiscox, Michael J., and Stephanie. Rickard. 2002. "Birds of a Different Feather? Varieties of Capitalism, Factor Specificity, and Inter-industry Labor Movements." Unpublished manuscript. Harvard University.

Hiscox, Michael J., and Scott. L. Kastner. 2002. "A General Measure of Trade Policy Orientations: Gravity-Model-Based Estimates for 82 Nations, 1960-92." Unpublished manuscript. Harvard University.

Huber, John D., and Powell, G. Bingham Jr. 1994 "Congruence between Citizens and Policymakers in Two Visions of Liberal Democracy." World Politics 46 (3): 291-326.

Hummels, David, and V. Lugovskyy. 2006. "Are Matched Partner Trade Statistics a Usable Measure of Transportation Costs. Review of International Economics 14 (1): 69-86.

Hurlin, Christophe, and Baptiste Venet. 2003. "Granger Causality Tests in Panel Data Models with Fixed Coefficients." Unpublished manuscript. University of Paris IX.

International Labor Organization, ILO. 2005. Key Indicators of the Labor Market. $4^{\text {th }}$ ed $C D-R O M$.

International Monetary Fund. 2004. Government Financial Statistics (CD- ROM).
International Monetary Fund. 2004. Direction of Trade Statistics (CD-ROM).

International Social Security Administration. 2004. Social Security Programs Throughout the World. Office of Policy Data, Geneva, Switzerland.

Irwin, Douglas A. 1994. "The Political Economy of Free Trade: Voting in British General Election of 1906." Journal of Law and Economics 37 (1): 75-108.

Irwin, Douglas A. 1996. "Industry or Class Cleavages over Trade Policy? Evidence from the British General Election of 1923." In The Political Economy of Trade Policy: Papers in Honor of Jagdish Bhagwati, ed. Robert C. Feenstra, Gene M. Grossman and Douglas A. Irwin. Cambridge, MA: MIT Press, 53-75.

Iverson, Torben, and David Soskice. 2006. "Electoral Institutions and the Politics of Coalitions: Why Some Democracies Redistribute More than Others." American Political Science Review 100 (2): 165-81.

Jensen, J. Bradford, and Lori G. Kletzer. 2005. "Tradable Services: Understanding the Scope and Impact of Services Offshoring." In Offshoring White-Collar Work, ed. Susan M. Collins and Lael Brainard. Washington, DC: Brookings Institute, 75-134.

Kono, Daniel Y. 2006. "Optimal Obfuscation: Democracy and Trade Policy Transparency." American Political Science Review 100 (3): 369-84.

Korenman, Sanders, and David Neumark. 2000. "Cohort Crowding and Youth Labor Markets: A Cross-National Analysis." In Youth Employment and Unemployment in Advanced Countries, ed. David Blanchflower and Richard Freeman. Chicago: University of Chicago Press, 57-105.

Lavergne, Real P. 1983. The Political Economy of US Tariffs. Toronto: Academic Press.

Leamer, Edward E. 1988. "Measures of Openness." In Trade Policy Issues and Empirical Analysis, ed. Robert Baldwin. Chicago: University of Chicago Press, 147-200.

Lee, Jong-Wha. 1992. "International Trade, Distortions and Long-Run Economic Growth.” IMF Working Papers 92/90, International Monetary Fund.

Lijphart, Arend. 1999. Patterns of Democracy. New Haven, CT: Yale University Press.

Magee, Stephen P. 1978. "Three Simple Tests of the StolperSamuelson Theorem." In Issues in International Economics, ed. Peter Oppenheimer. Oriel Press: Stockfield, 138-53.

Mansfield, Edward D., and Marc L. Busch. 1995. "The Political Economy of Non-tariff Barriers: A Cross-National Analysis." International Organization 49 (4): 723-49.

Mayda, Anna Maria, and Dani Rodrik. 2005. "Why Are Some Individuals (and Countries) More Protectionist than Others?" European Economic Review 49 (6): 1393-1430.

Mayer, Wolfgang. 1984. "Endogenous Tariff Formation." American Economic Review 74 (5): 970-85.

McGillivray, F. 2004. Privileging Industry: The Comparative Politics of Trade and Industrial Policy. Princeton, NJ: Princeton University Press.

Milner, Helen V., and Benjamin Judkins. 2004 "Partisanship, Trade Policy, and Globalization: Is There a Left-Right Divide on Trade Policy?" International Studies Quarterly 48 (1): 95-119.

Milner, Helen V., Edward Mansfield, and Jon Pevehouse. 2007. "Vetoing Cooperation: The Impact of Veto Players on International Trade Agreements." British Journal of Political Science 37 (3): 403-32. 
Milner, Helen, and Keiko Kubota. 2005. "Why the Move to Free Trade? Democracy and Trade Policy in the Developing Countries." International Organization 59 (1): 107-43.

Myerson, Roger. 1993. "Incentives to Cultivate Favored Minorities under Alternative Electoral Systems." American Political Science Review 87 (4): 856-69.

Nickell, Stephen. 1985. "Error Correction, Partial Adjustment and All That: An Expository Note." Oxford Bulletin of Economics and Statistics 47 (2): 119-29.

Nielson, Daniel. 2003. "Supplying Trade Reform: Political Institutions and Liberalization in middle-income Presidential Democracies." American Journal of Political Science 47 (3): 470-91.

Penn World Tables. 2004. Version 6.1. http://pwt.econ.upenn. edu/php_site/pwt_index.php

Powell, G. Bingham Jr. 2000. Elections as Instruments of Democracy: Majoritarian and Proportional Visions. New Haven, CT: Yale University Press.

Powell, G. Bingham Jr., and Georg Vanberg. 2000. "Election Laws, Disproportionality and the Left-Right Dimension." British Journal of Political Science 30 (3): 383-411.

Przeworski, Adam, Michael E. Alvarez, Jose Antonio Cheibub, and Fernando Limongi. 2000. Democracy and Development: Political Institutions and Well-Being in the World, 1950-1990. New York: Cambridge University Press.

Rama, Martín. 2003. "Globalization and Labor Markets." World Bank Research Observer 18 (2): 159-86.

Rogowski, Ronald. 1987. "Trade and the Variety of Democratic Institutions." International Organization 41 (2): 203-24.

Rose, Andrew. 2004a. "Do We Really Know that the WTO Increases Trade?" American Economic Review 94 (1): 98-114.

Scheve, Kenneth, and Matthew J. Slaughter. 2001. "What Determines Individual Trade-Policy Preferences?" Journal of International Economics 54 (2): 267-92.
Spiezia, Vincenzo. 2003. "Geographic Concentration of Production and Unemployment in OECD Countries." Unpublished manuscript. OECD Statistics and Indicators Unit, Paris.

Taagepera, Rein, and Matthew Shugart. 1989. Seats and Votes: The Effects and Determinants of Electoral Systems. New Haven, CT: Yale University Press.

Thies, Cameron G., and Schuyler Porche. 2007. "The Political Economy of Agricultural Protection." Journal of Politics 69 (1): 116-27.

Tomz, Michael, Judith Goldstein, and Douglas Rivers. 2007. "Do We Really Know That the WTO Increases Trade? Comment." American Economic Review 97 (5): 2005-18.

United Nations Industrial Development Organization, 2003. UNIDO Industrial Statistics Database, 3- and 4-Digit Level of ISIC Code UNIDO, Vienna.

Vodopivec, M. 2004. "Income Support Systems for the Unemployed: Issues and Options.” World Bank: Social Protection Discussion Paper.

Wacziarg, Romain, and Jessica Seddon Wallack, 2004. "Trade Liberalization and Inter-sectoral Labor Movements." Journal of International Economics 64 (2): 411-39.

World Bank. 2003. World Development Indicators [CD-Rom].

Bumba Mukherjee is an associate professor of political science, Penn State University, University Park, PA 16802.

Dale L. Smith is an associate professor of political science, Florida State University, Tallahassee, FL 32306.

Quan Li is a professor of political science, Texas A\&M University, College Station, TX 77840. 